\title{
TEXT Editorial
}

\section{'The problem has more to do with creative writing courses...'?}

Recently, the following letter to the editor appeared in the 'Your View' column of the Weekend Australian Review:

Laurie Hergenhan's column on Australian literature (Review, March 10-11) was thoughtful and accurate. However, I believe some blame must rest on writers. Recently a friend gave me a bundle of Ozlit magazines, which I stacked by my bedside table, dipping into them over the midnight watches. The selfconscious cleverness, coupled with the arrogance of inaccessibility (certainly with the poetry) was palpable. As far as I'm concerned, the Ozlit problem is twofold. On the one hand, profit-driven publishing has meant no time to notice, let alone nurture, new talent, and on the other there are too many wannabes who couldn't give a stuff about a readership beyond their mates. I know there are good Australian writers out there. The problem has more to do with creative writing courses encouraging a cult of authorship fuelled by ego rather than talent.

Ian McFarlane Beauty Point, Wallaga Lake, NSW

(Weekend Australian Review March 24-25, 2007: 2)

The letter paints with a broad brush, and shoots with a scattergun, but the culprits are cross-haired: it's creative writing courses that have caused the crisis. Their encouragement of 'a cult of authorship fuelled by ego rather than talent' has not only let the national literature down: it is the reason $\mathrm{Mr}$ McFarlane did not enjoy his bundle of borrowed Ozlit magazines at midnight.

\section{A cult of authorship?}

There are several factors militating against the notion that writing courses encourage a 'cult of authorship'. For a start, the concept of authorship has been under pressure during the last 10 years of creative writing teaching - due to Roland Barthes' provocative notions - and only at their own peril might creative writing courses have proposed a cult for living authors while the quintessential author is dead. Such cults may belong to artistic training of half a century - or two millennia - ago, but Barthes' ideas have firmly swung perception towards the opposite notion: towards cults of readership. In this 
climate, budding authors (along with those more established) necessarily feel challenged.

Second, in what area of education and professionalism is there not a 'cult of success' created for the up-coming apprentices? Without the supposed promise of achievement at the completion of the qualifying period, who would bother to train? But in the last 10 years of creative writing teaching there has been a significant shift away from any sort of cult status for training. Students don't enrol in large numbers in order to become best-selling authors any more. They enrol to learn about writing.

A decline in enrolments in traditional literature courses has been partly taken up by an increase in enrolments in writing courses. This has been a swapping of education involving reading to expand the mind for one of writing to expand the mind. This is to some extent an exchange of a passive behaviour for an active one, but in an era when more writing is being done and published internationally than ever before, it is a logical development:

... humans used to write diaries or letters which passed in manuscript form between select individuals; now we have the technology to write instantly, to send thoughts and observations, to the entire world. The technology and the way we have taken to it, has meant that writing has become more public as well as more personal. This is different from an age of reading where a select few writers were formally published, or circulated their works in private manuscripts, or hung out their shingles to write words for others. What are the implications of this universality of publication for our discipline? The new age of writing has brought with it a new growth of language and of thinking about writing. (Brady and Krauth Creative Writing: Theory beyond practice 2006: 16)

In this new context where young people communicate by writing as never before (on the internet and by texting on mobile phones, both of which are very economically done) there is logically a new interest in the expanded possibilities of writing. The power of publication and broadcast is now lodged in the source-writer's hands; published or broadcast writing is not an activity for a future benefit, it is an immediate communication.

Today's students have a different idea of a writing course from that of the older generation (who may include their teachers). Writer/teacher Venero Armanno has alluded to this, as reported by Elizabeth Meryment:

[Armanno] points out that the study of creative writing is not necessarily about getting published. Learning to write is the key element. "The creative writing program is not overtly designed or intended to get students' work published. That is a by-product that might come after five or 10 or 15 years. The aim is to teach writing as a craft and a skill, and it is wrong and counter-productive for students to believe that their projects will or should get published," he says. (Elizabeth Meryment 'The Write Course', The Courier-Mail 8 February 2003: BAM 4)

The teaching of creative writing in its own right, and for its own sake, is no less likely for good than the teaching of reading of creative works in its own right and for its own sake has been as the project of English studies in the last century and more. Not everyone who studied English literature became a 
literary critic; not everyone currently studying writing will become a writer. Many of those who studied English literature became better readers, writers and thinkers; many of those studying writing today will become the same. Also, some of those who have studied either literature or writing did - and do so merely as a way of providing spakfilla for the gaps in their degrees.

The idea of 'a cult of authorship' has about it a hint of mysticism and intrigue. The opposite is clearly the case for writing programs: students now enrol in these courses for practical and overt reasons concerned with future personal and career communications demands.

\section{Ego rather than talent?}

It is interesting - and somewhat mystifying - that Mr McFarlane should present 'ego' and 'talent' as opposites in the context of writing. He suggests that success in writing rests on the selecting of one of these against the other. He doesn't consider the proposition that a writer might need both qualities, and perhaps both in abundance.

A deal of talent as a writer will get you part of the way, but in order to take on the weight of the culture - the prevailing politics, the prevailing fashion, the prevailing thinking, the prevailing follies - you need more than talent. You need the commitment that comes from innate courage. Significant writers in the culture are called upon to speak out significantly - and for this one needs talent and self-belief together.

A creative writing course that teaches writers to reduce their egos - especially to the extent that they become pussyfooting yes-men and yes-women - is not doing its job vis-à-vis writing's project to critique and advance the culture. Writers need to be impassioned, pro-active and self-confident, while also being talented at empathising with the range of others' viewpoints. A writing course of value to students teaches a balance between the talents they bring to class, the enhancement of those talents, and the forcefulness they need to get their messages to the world.

Mr McFarlane gets 4.5 out of 10 for his letter. He raises significant issues, but fails to deal with them in a researched manner.

\section{Other points of view}

The contributors to this issue of TEXT have, like Mr McFarlane, taken a close and cool look at what is going on in creative writing schools, and in the relationship between the writing self and the reading other. Like McFarlane, they notice gaps in the space between discourse and practice, but then they engage intellectually, critically and passionately to find ways of better understanding what is going on in writing, in creative writing courses, and in reading practice.

Ten writers have contributed the essays published here, and between them they cover a wealth of topics. Voice - of the text, of the writer, of the body writing, of the reader - is explored by Debra Adelaide, Michael Beresford and Claire Woods. What is that mysterious thing called 'voice'? How does it emerge in writing, and in a writer's work? What is its relation to the body, and to the whole domain of feeling and the visceral rather than the abstract and propositional that tends to dominate academic logic? These questions are further developed by Brad Haseman, Kevin Brophy and Erin Wilcox, who take on the big topics of practice-led, rather than problem-led, research (Haseman), 
the creative PhD (Brophy), and Zizek's notion of the unconscious and desire (Wilcox). Training students how to find and cultivate voice, how to recognize the unconscious desire that drives practice, and how to balance on the tightrope that stretches between self and other, logic and emotion, art for art's sake and professional practice are also examined by Donna Lee Brien (looking at crosscultural teaching), Phil Edmonds (on Wet Ink magazine), and Keri Glastonbury (on creative/community practice). And Emily Sutherland picks up on many of these issues in her essay on the narrowing space between 'real life' people and characters in texts, where she examines what lies across the divides of physiology and nomination, or material presence and abstract concepts.

These ten very different essays, in short, capture two issues that are of central importance to writers - and, it seems fair to say, to readers. The first is the issue of attention. They point out that writers work best by paying attention to what is outside them; to what other people do and speak and gesture: to who our readers might be and what they are likely to make of our words; and to that which drives us in our own practice, the 'Real of our desire'. The second, a related issue, is an emphatic call to writers to remember the body, and that which lies outside the domain of logical propositional discourse. How do we cultivate an outward, reader-directed textured and embodied voice that makes the text present for its readers, and indeed for itself (Adelaide, Beresford)? How do we support our students in producing work that is not merely 'well crafted', but also contains substance (Brophy, Edmonds)? How do we test the 'truths' that are presented to us as teachers, so that we can work with students to find what it means to write in and across cultures (Woods, Brien)? How do we locate our own writing, and our identity as writers, within an ethical and communal framework (Glastonbury, Sutherland)? And how do we move out from the 'shadow of Socrates' and find ways to explore the non-discursive, the affectual, and that which lies beyond logic (Haseman, Wilcox)?

In this issue of TEXT you will find some ways of thinking through, and of attempting answers to, these questions. Along with the essays are reviews by Moya Costello, Scott Downman, Valerie Jeremijenko, Nigel Krauth and Theresa Lauf; and poems by Kevin Brophy, Joel Deane and Stephen Lawrence. All challenge their readers to look at writing from a different point of view; to indulge in playful misreadings; to look at reading from a different point of view; and above all, to relish the flavour and texture of words, phrases and lines put together as much for their thrum and pulse as for their logical sense.

Nigel Krauth and Jen Webb

Editors 


\section{TEXT}

Vol 11 No 1 April 2007

http://www.griffith.edu.au/school/art/text/

Editors: Nigel Krauth \& Jen Webb

Text@griffith.edu.au 